Taksonomia 28

ISSN 1899-3192

Klasyfikacja i analiza danych - teoria i zastosowania

e-ISSN 2392-0041

\title{
Marcin Salamaga
}

Uniwersytet Ekonomiczny w Krakowie

e-mail: salamaga@uek.krakow.pl

\section{ZASTOSOWANIE ANALIZY KORESPONDENCJI DO BADANIA MOTYWÓW PODEJMOWANIA BEZPOŚREDNICH INWESTYCJI ZAGRANICZNYCH PRZEZ POLSKIE FIRMY ${ }^{1}$}

\section{THE APPLICATION OF CORRESPONDECE ANALYSIS TO THE IDENTIFICATION OF FACTORS SUPPORTING THE FDI OF POLISH COMPANIES}

DOI: $10.15611 /$ pn.2017.468.21

JEL Classification: C38, F21

Streszczenie: W artykule przedstawiono wielowymiarową analizę statystyczną polskich firm ze względu na motywy podejmowania bezpośrednich inwestycji zagranicznych (BIZ). Uwzględniono czynniki o charakterze kosztowym, rynkowym, efektywnościowym, prawnym, społecznym i politycznym, którymi firmy kierują się, rozważając możliwość eksportu BIZ. Celem artykułu jest wyodrębnienie obszarów działalności firm, w których polityka inwestycyjna w zakresie priorytetów przy podejmowaniu decyzji o uruchomieniu BIZ wykazuje największe podobieństwo. Podstawowym narzędziem badawczym wykorzystanym w opracowaniu jest analiza korespondencji uzupełniona o metody analizy skupień. Wyniki takiego badania mogą stanowić wsparcie w procesie segmentacji polskich przedsiębiorstw podejmujących BIZ. Analizę wykonano przy wykorzystaniu danych pochodzących z badania ankietowego przeprowadzonego wśród polskich przedsiębiorstw podejmujących BIZ lub planujących tę formę inwestowania.

Słowa kluczowe: analiza skupień, analiza korespondencji, badanie ankietowe, BIZ, destynacje BIZ.

Summary: The purpose of this article is to identify the main factors determining the choice of Polish foreign direct investment (FDI) destination. The research includes the cost factors, market factors, efficiency factors, law factors, social factors, and political factors, which may be important in the search for the beneficiaries of FDI. The paper uses Correspondence Analysis. The results of this research enables the creation of companies profiles which have similar investment policy in terms of priorities of the choice of investment destination. In the research

${ }^{1}$ Publikacja została sfinansowana ze środków przyznanych Wydziałowi Zarządzania Uniwersytetu Ekonomicznego w Krakowie, w ramach dotacji na utrzymanie potencjału badawczego. 
was used data from a survey conducted among Polish companies investing in FDI or planning this form of investing.

Keywords: Cluster Analysis, Correspondence Analysis, survey, FDI, FDI destination.

\section{Wstęp}

Bezpośrednie inwestycje zagraniczne (BIZ) są postrzegane jako bardzo ważna i bezpieczna forma międzynarodowych przepływów kapitałowych, wspomagająca procesy rozwojowe i restrukturyzacyjne w wielu krajach. Często są one także efektywnym, a niekiedy jednym sposobem uzyskiwania dostępu do nowoczesnych technologii w obszarze produkcji, zarządzania; umożliwiają także eksport towarów oraz usług na nowe zagraniczne rynków zbytu. Bezpośrednie inwestycje zagraniczne są transferowane najczęściej przez kraje wysoko rozwinięte, dysponujące nowoczesnymi technologiami z odpowiednio wysoką akumulacją kapitału. Trudno obecnie zaliczyć Polskę do tego typu krajów, ale i niektóre polskie firmy od kilku lat coraz częściej poszukują możliwości inwestowania na rynkach zagranicznych z wykorzystaniem BIZ. Głównymi odbiorcami polskich BIZ są kraje Unii Europejskiej. W 2014 r. wartość zasobów polskich inwestycji bezpośrednich ulokowanych na terenie UE stanowiła około $74 \%$ całkowitej wartości BIZ eksportowanych z Polski ${ }^{2}$. Niezależnie od tego wiele polskich firm szuka także pozauropejskich destynacji dla swoich inwestycji bezpośrednich, biorąc pod uwagę m.in. niższe koszty czynników produkcji czy dostęp do nowych rynków zbytu.

Motywom podejmowania bezpośrednich inwestycji zagranicznych poświęca się wiele uwagi zarówno w krajowej, jak i zagranicznej literaturze przedmiotu (por. [Dunning 2004; Fry 1993; Jun, Singh 1996; Mottaleb 2007]). Znane są różne klasyfikacje determinantów napływu BIZ, wśród których często powtarzają się czynniki ekonomiczne (kosztowe, rynkowe, handlowe), instytucjonalne, prawne i inne kształtujące tzw. klimat inwestycyjny [Ozawa, Lukas 1993; Pilarska 2005; Rymarczyk 2004]. Badania empiryczne prowadzone dotychczas w zakresie motywów podejmowania BIZ dostarczają mniej więcej podobnych wyników. Zgodnie z nimi za czynniki decydujące o uruchomieniu BIZ inwestorzy uważają: perspektywiczny rynek zbytu, zwiększenie możliwości eksportowych i niskie koszty pracy [Karpińska-Mizielińska, Smuga 2007; Kowalewski, Radło 2013; Salamaga 2015].

Dynamicznie zmieniająca się sytuacja geopolityczna i społeczna na świecie może powodować inne rozłożenie akcentów w motywach podejmowania BIZ, a co za tym idzie - wymusza często decyzje o zmianie kierunku BIZ. Zatem lokalizacje BIZ, które uważane były do pewnego czasu za atrakcyjne dla inwestorów zagranicznych, mogą przestać takimi być. Stąd decyzja o wyborze kierunku eksportu BIZ

\footnotetext{
${ }^{2}$ https://www.mr.gov.pl/ (20.10.2016).
} 
musi być bardzo przemyślana i wyważona. Dlatego też konieczne jest systematyczne badanie motywów podejmowania BIZ w połączeniu z preferowanymi wyborami destynacji tej formy lokaty kapitału. $W$ istniejących opracowaniach najczęściej motywy BIZ i wybierane destynacje badane są niezależnie od siebie z pominięciem narzędzi ilościowych umożliwiających stwierdzenie rzeczywistych relacji pomiędzy tymi kategoriami. Zastosowanie np. metod wielowymiarowej analizy statystycznej pozwala na wykrycie faktycznych powiązań pomiędzy zmiennymi i wzmacnia moc formułowanych wniosków. W niniejszym artykule do wykrycia powiązań pomiędzy motywami BIZ i wyborami destynacji BIZ przez polskie firmy została zastosowana jedna $\mathrm{z}$ takich metod, a mianowicie analiza korespondencji. Umożliwiła ona zrealizowanie głównego celu pracy, jakim jest wyodrębnienie profili badanych przedsiębiorstw podobnych pod względem zagranicznej polityki inwestycyjnej w zakresie wyboru destynacji BIZ. Zaproponowane postępowanie badawcze należy uznać za oryginalne w kontekście celu badawczego. Dodatkowo wyniki przedstawione w artykule odzwierciedlają aktualne nastroje inwestycyjne polskich inwestorów, które znajdują wyraz w preferencjach co do wyboru kierunków BIZ.

\section{Metoda badania}

Do wykrycia zależności pomiędzy motywacjami podjęcia BIZ i wyborami ich destynacji wykorzystano analizę korespondencji. Dzięki tej metodzie możliwe jest przeanalizowanie współwystępowania obiektów (destynacji BIZ) i kategorii cech (motywów podejmowania BIZ, branż gospodarczych), co w przypadku przedmiotowego badania umożliwia wyodrębnienie profili przedsiębiorstw o zbliżonych kryteriach wyboru destynacji BIZ. Wybór tego narzędzia badawczego był podporządkowany celowi pracy, a z drugiej strony wynikał z charakteru zmiennych. Kluczowe były tu cechy mierzone na skalach słabych: nominalnej (motywy eksportu BIZ, branże ankietowanych przedsiębiorstw) i porządkowej (preferowane destynacje BIZ). Z uwagi na fakt, że jedna $\mathrm{z}$ cech była mierzona na skali porządkowej (respondenci mieli możliwość porządkowania zgodnie ze swoimi preferencjami 17 krajów - potencjalnych beneficjentów BIZ), to $\mathrm{w}$ analizie korespondencji zastosowano tzw. podwajanie obserwacji [Greenacre 1993; Blasius 2001]. W celu zbadania relacji pomiędzy wyborem destynacji BIZ i branżą, w której lokowane są inwestycje bezpośrednie, pod uwagę wzięto te destynacje, które wskazywane były jako najbardziej preferowane (oznaczone symbolami krajów), i te, które były najmniej preferowane (oznaczone symbolem kraju poprzedzonym znakiem $\sim$ ). Dla takiego zestawu kategorii destynacji i branż zbudowano tabelę kontyngencji, która posłużyła do wykonania analizy korespondencji. Wykorzystanie antycech w procesie podwajania obserwacji pozwala ocenić, jakie branże absorbujące BIZ i jakie motywy podejmowania BIZ determinują wybór jednych destynacji BIZ i dyskwalifikują wybór innych destynacji. Wymiar przestrzeni rzutowania punktów $\mathrm{w}$ analizie korespondencji określono za pomocą kryterium osypiska [Clausen 1998]. 


\section{Charakterystyka próby badawczej}

Dane do analizy uzyskano na podstawie badania ankietowego przeprowadzonego w 2016 r. wśród polskich firm, które lokowały bezpośrednie inwestycje za granicą bądź też dysponowały potencjałem umożliwiającym taką formę inwestowania. Badaniem objęto 750 firm reprezentujących różne branże gospodarki. Po ostatecznej selekcji poprawnie wypełnionych ankiet w końcowej analizie uwzględniono 408 przedsiębiorstw. Wśród badanych firm dominowały przedsiębiorstwa $\mathrm{z}$ branży przetwórstwa przemysłowego (38\%). Firmy zajmujące się handlem i naprawą pojazdów samochodowych stanowiły $14 \%$, branżę budowlaną reprezentowało $12 \%$ firm, działalność profesjonalną, naukową i techniczną - 15\% firm, działalność informacyjną i komunikacyjną - 6\%. Firmy należące do pozostałych branż zaliczono do pozostałych sekcji PKD i było ich ok. 15\%. Wśród tych ostatnich dominowały firmy z branży usług finansowych i ubezpieczeniowych. $Z$ analizy ankiet wynika, że największy odsetek firm stanowią te, które są skłonne zainwestować w BIZ kwotę od 5 do $10 \mathrm{mln}$ EUR (42\% firm). 30\% ankietowanych firm może przeznaczyć kwotę powyżej $10 \mathrm{mln}$ EUR na tego typu inwestycje, a 13\% planuje inwestycje bezpośrednie w kwocie mniejszej niż 1 mln EUR. Firmy poddane badaniu miały wskazać motywy podejmowania BIZ oraz destynacje dla własnych BIZ zgodnie ze swoimi preferencjami inwestycyjnymi. Spośród determinantów BIZ były takie, które reprezentowały m.in. czynniki ekonomiczne, efektywnościowe, prawne i polityczne. Respondenci oceniali również atrakcyjność destynacji dla planowanych bezpośrednich inwestycji zagranicznych. Mogli oni uporządkować zgodnie ze swoimi preferencjami kilkanaście destynacji, wśród nich znalazły się zarówno kraje będące już dzisiaj beneficjentami BIZ pochodzącymi z Polski, jak i kraje, które mogą być potencjalnie atrakcyjne dla polskich inwestorów w niedalekiej przyszłości. Wśród ocenianych destynacji znalazły się m.in. kraje reprezentujące UE, pozaunijne kraje europejskie, a także kraje leżące w Azji, Afryce, Ameryce Północnej i Ameryce Południowej.

\section{Wyniki badań empirycznych}

W pierwszej części badania posłużono się analizą korespondencji w celu ustalenia współwystępowania branż i destynacji BIZ. Analizę korespondencji przeprowadzono tu w oparciu o tabelę kontyngencji z liczebnościami współwystępowania kategorii cech nominalnych [Greenacre 1993; Blasius 2001; Stanimir 2005]. Wyniki tego etapu badania pozwolą ustalić prawidłowości pomiędzy branżą lokowania BIZ a motywami ich podejmowania.

Na potrzeby analizy korespondencji przyjęto następujące symbole dla rozważanych destynacji BIZ: CH - Szwajcaria, CN - Chiny, CY - Cypr, CZ - Republika Czeska, DE - Niemcy, EG - Egipt, ES - Hiszpania, FR - Francja, GB - Wielka Brytania, IN - Indie, LU - Luksemburg, NO - Norwegia, RU - Rosja, TR- Turcja, 
UA - Ukraina, US - Stany Zjednoczone, Ot - inne kraje. Antycechy, czyli najmniej preferowane destynacje, oznaczono znakiem , po którym następuje kod kraju.

Ankietowane firmy lokują lub zamierzają lokować BIZ w branże oznaczone następującymi symbolami: $m a$ - przetwórstwo przemysłowe, $b u$ - budownictwo, tr - handel, naprawa pojazdów samochodowych, co - informacja i komunikacja, $s c$ - działalność profesjonalna, naukowa i techniczna, o - pozostałe. Wymiar przestrzeni rzutowania obiektów i cech ustalono za pomocą kryterium osypiska. $\mathrm{Z}$ rys. 1 wynika, że wyhamowanie spadku wartości własnych odpowiedniej macierzy $\mathrm{X}^{\mathrm{T}} \mathrm{X}$ (gdzie macierz X zawiera standaryzowane różnice wszystkich kombinacji obiektów i wartości cech) następuje przy liczbie wymiarów równej 3 . W takiej przestrzeni następuje wyjaśnienie ok. 84\% zmienności badanych cech.

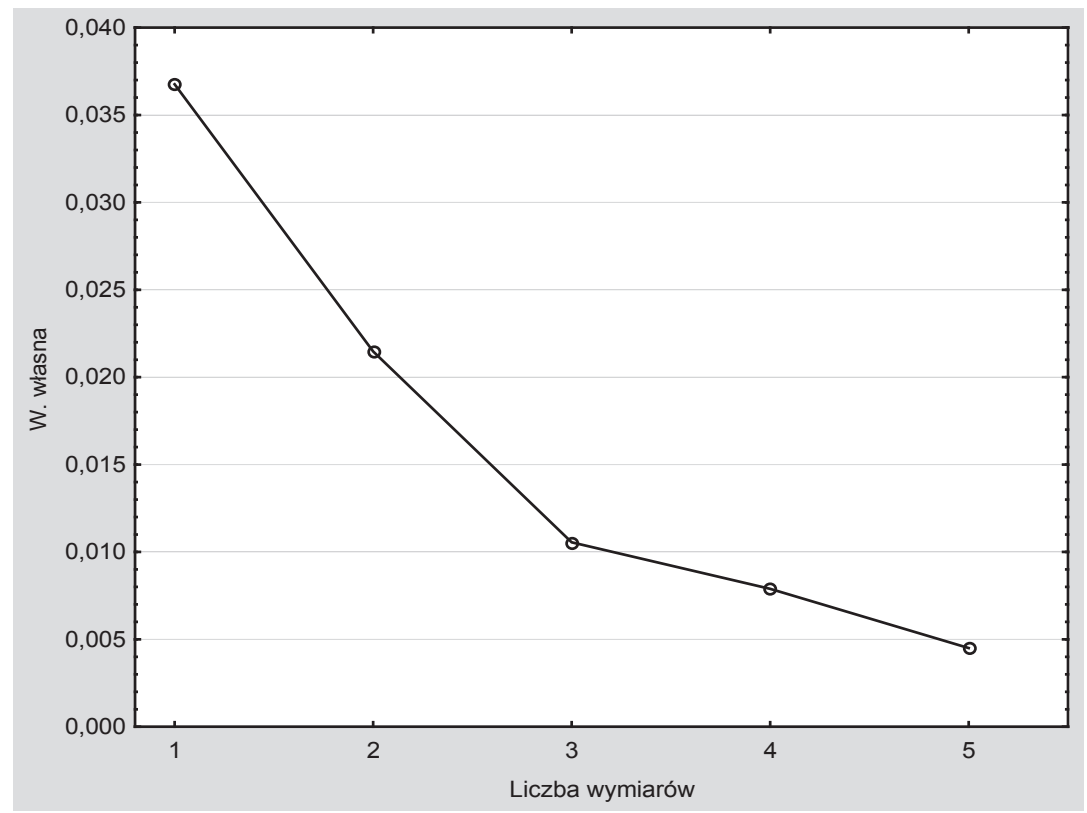

Rys. 1. Wartości własne w zależności od wymiaru przestrzeni (kryterium „osypiska”)

Źródło: opracowanie własne.

Wartość statystyki chi-kwadrat wynosi 347,03 (wartość $p=0,000$ ), a zatem zależność pomiędzy branżami gospodarczymi i rozważanymi destynacjami BIZ jest istotna statystycznie. Jakość odwzorowania rzeczywistych wystąpień poszczególnych kategorii cech wybranej przestrzeni oceniono za pomocą miernika jakości odwzorowania (quality of display of a point) [Stanimir 2005], którego wartość informuje, jaka część inercji rozważanej kategorii jest zawarta w wybranej przestrzeni rzutowania. W przypadku ponad $76 \%$ destynacji BIZ wartość tego miernika jest wyższa od 0,7 , a dla $32 \%$ destynacji była ona wyższa od 0,9 . Wobec tego utrata 
informacji o faktycznym charakterze cechy destynacja BIZ przy założeniu trójwymiarowej przestrzeni rzutowania punktów nie jest relatywnie duża. Jeszcze lepiej pod tym względem wygląda sytuacja w przypadku cechy branża gospodarcza, gdzie w $67 \%$ przypadków wartość miernika jakości odwzorowania przekracza 0,9 .

Ponieważ interpretacja analizy korespondencji na rysunku w przestrzeni trójwymiarowej może być kłopotliwa, więc zdecydowano się na pośredni sposób przedstawienia przedmiotowych wyników, posługując się analizą skupień. Grupowanie branż, w których działają firmy, oraz destynacji BIZ przeprowadzono, posługując się zmiennymi, którymi były wartości współrzędnych odpowiednich kategorii cech w przestrzeni trójwymiarowej. Tym samym grupowanie odbywa się na podstawie informacji o położeniu punktów reprezentujących kategorie cech w analizie korespondencji [Stanimir 2005]. Posłużono się przy tym metodą Warda z odległością euklidesową (rys. 2). Biorąc pod uwagę wartość współczynnika korelacji kofenetycznej [Sokal, Rohlf 1962], wynoszącą 0,503, można stwierdzić, że dendrogram umiarkowanie dobrze odzwierciedla zarówno podobieństwo, jak i różnice pomiędzy obiektami. Optymalną liczbę skupień określono w oparciu o pierwszy wyraźny przyrost odległości aglomeracyjnej dla kolejnych etapów wiązania.

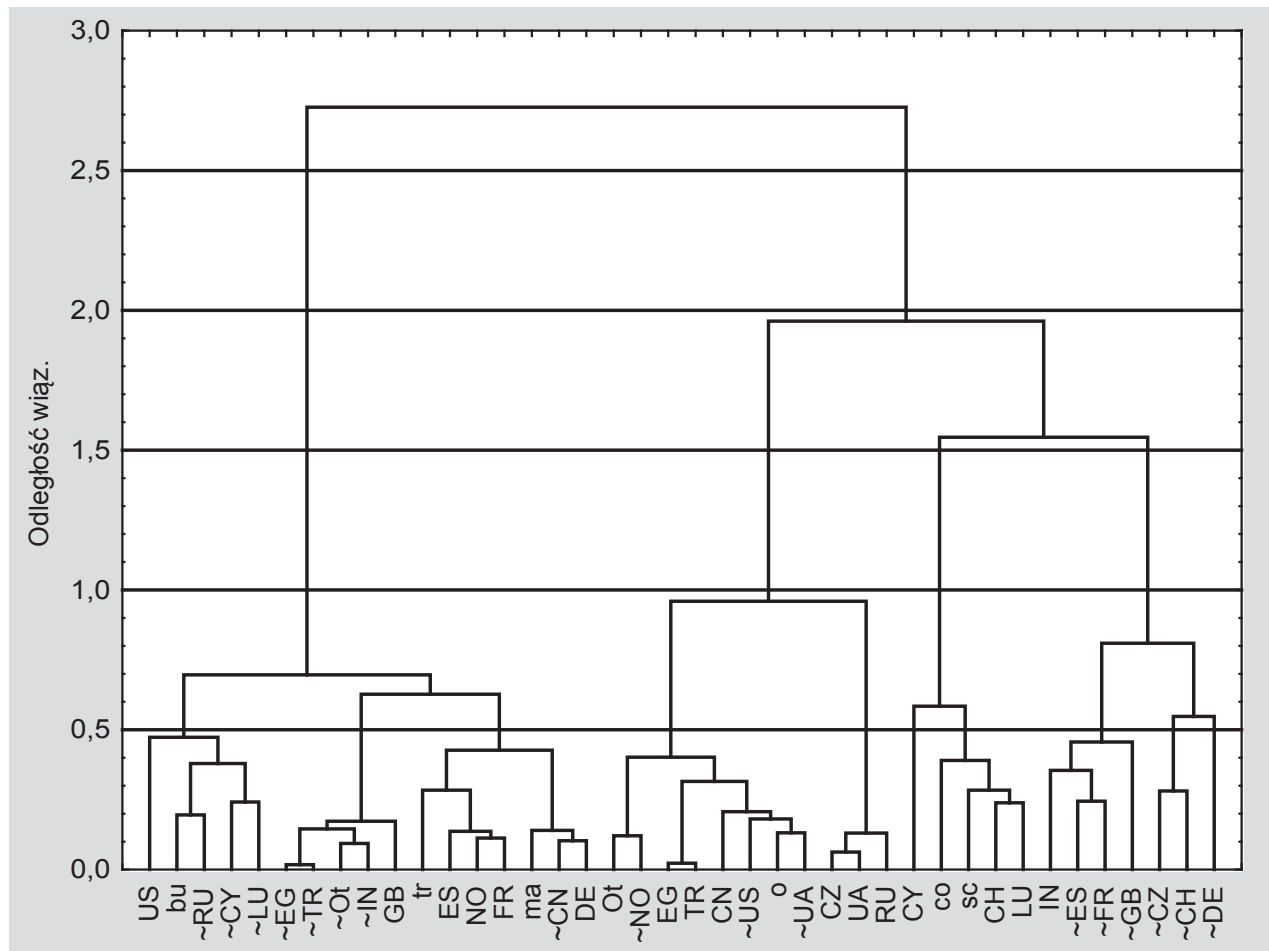

Rys. 2. Wyniki grupowania branż gospodarczych i destynacji BIZ

Źródło: opracowanie własne. 
Na podstawie tego kryterium przycięto dendrogram z rys. 2 na wysokości wiązania 0,8 , otrzymując 6 jednorodnych skupień. Analizując ich skład, można wyciągnąć następujące wnioski:

- firmy z branży budowlanej, handlowej i przetwórstwa przemysłowego za atrakcyjne kierunki dla swoich BIZ uważają: Niemcy, Stany Zjednoczone, Norwegię, Hiszpanię, Francję i Wielką Brytanię, a za nieatrakcyjne m.in. następujące destynacje: Rosja, Cypr, Luksemburg, Egipt, Turcja, Indie, Chiny,

- firmy reprezentujące działalność profesjonalną, naukowa i techniczną, a także działające w branży informacyjnej i komunikacyjnej za atrakcyjne dla swoich BIZ uważają: Luksemburg, Cypr i Szwajcarię,

- przedsiębiorstwa z innych branż chętnie jako kierunek BIZ wskazywały: Egipt, Turcję, Chiny, natomiast pomijane przez nie kierunki eksportu BIZ to: Norwegia, Stany Zjednoczone i Ukraina.

W dalszej części opracowania za pomocą analizy korespondencji badano współwystępowanie motywów podejmowania BIZ oraz destynacji BIZ uważanych za atrakcyjne lub nieatrakcyjne. W badaniu przyjęto następujące oznaczenia dla motywów BIZ: $l c$ - koszty pracy, $n p$ - ceny zasobów naturalnych, $n s$ - poszukiwanie niszy rynkowej, $c c$ - kooperacja z lokalnymi firmami, $m p$ - modernizacja metod produkcji, $t p$ - polityka celna i podatkowa, $e c$ - prawodawstwo gospodarcze i administracyjne, $s q$ - kwalifikacje kadry pracowniczej, $s w$ - poziom zamożności społeczeństwa, $g i$ - stopień ingerencji państwa w gospodarkę, $p s$ - stabilność polityczna, $n m$ - nowe rynki zbytu.

Posługując się kryterium osypiska, stwierdzono, że wystarczający wymiar przestrzeni rzutowania punktów wynosi 2 . W tej przestrzeni wyjaśnione jest prawie $70 \%$ zmienności danych wejściowych. $Z$ kolei wartość statystyki chi-kwadrat wynosi 728,34 (wartość $p=0,000$ ), co jest wynikiem wskazującym na istotny związek pomiędzy motywami podejmowania BIZ i rozważanymi destynacjami. Jakość odwzorowania rzeczywistych wystąpień poszczególnych kategorii cech wybranej przestrzeni oceniono za pomocą miernika jakości odwzorowania. Dla połowy destynacji BIZ wartość tego miernika jest wyższa od 0,7 , a dla $38 \%$ z nich miernik ten przekracza wartość 0,8 . Podobnie inercje dla połowy rozważanych motywów podejmowania BIZ mają ponad 70-procentowy udział w przestrzeni rzutowania, a dla $33 \%$ motywów ten udział przekracza $80 \%$. Powyższe wyniki wskazują na umiarkowanie dobrą jakość odwzorowania współwystępowania kategorii. Analizując z kolei współczynniki korelacji punktów z osiami wymiarów, stwierdzamy, że z osią pierwszego wymiaru silniej skorelowana jest większość punktów reprezentujących destynacje BIZ (najsilniej - destynacja Cypru, dla której współczynnik korelacji wyniósł 0,815 ). Z kolei druga oś wymiaru przestrzeni nieco lepiej reprezentuje motywy podejmowania BIZ, gdyż większość kategorii tej cechy wykazuje silniejszy związek właśnie z drugą osią wymiaru przestrzeni (najwyższy współczynnik korelacji wynoszący 0,911 miało poszukiwanie niszy rynkowej).

Wyniki odpowiedniej analizy korespondencji przedstawia rys. 3. 


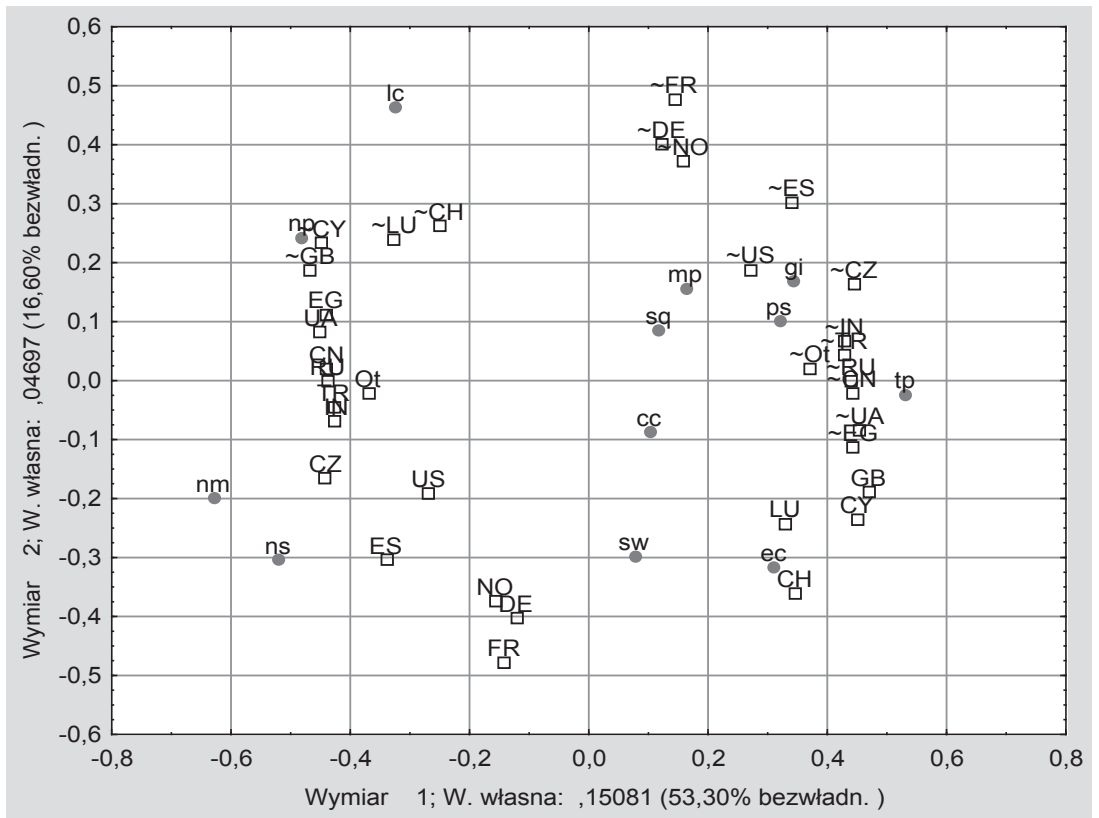

Rys. 3. Wykres konfiguracji punktów reprezentujących motywy oraz destynacje BIZ

Źródło: opracowanie własne.

Analizując wzajemne położenie punktów reprezentujących motywy i destynacje BIZ, można sformułować następujące wnioski:

- firmy, które wskazują na ceny czynników produkcji jako ważną determinantę BIZ, za atrakcyjne uważają lokalizacje BIZ w Egipcie i na Ukrainie, natomiast za nieatrakcyjne lokalizacje dla BIZ w Wielkiej Brytanii, na Cyprze, w Luksemburgu i Szwajcarii,

- przedsiębiorstwa, które jako czynnik podejmowania BIZ wskazują na nowe rynki zbytu i poszukiwanie niszy rynkowej, jako preferowane destynacje BIZ wymieniają Czechy, Hiszpanię i USA,

- firmy, które kierują się poziomem zamożności społeczeństwa, poszukując lokalizacji dla swoich BIZ, preferują Norwegię, Niemcy i Francję,

- przedsiębiorstwa, dla których ważne jest prawodawstwo gospodarcze i administracyjne w kraju, który jest beneficjentem BIZ, najczęściej wskazują na preferowaną lokalizację BIZ w Szwajcarii, Luksemburgu, na Cyprze, w Wielkiej Brytanii,

- firmy, które uważają za istotne: modernizację metod produkcji, stabilność polityczną w kraju beneficjenta BIZ, stopień ingerencji państwa w gospodarkę, kwalifikacje kadry pracowniczej za nieatrakcyjne uważają Czechy, Turcję, Indie, inne kraje (niewymienione w ankiecie) i co trochę zaskakuje Stany Zjednoczone. 
Powyższe wyniki wskazują, że wybierając destynacje w Europie Wschodniej lub na pozaeuropejskich rynkach wschodzących, firmy najczęściej kierują się motywami rynkowymi i kosztowymi. Inwestycje bezpośrednie w tych rejonach najczęściej kierowane są do różnych branż gospodarczych. Jeśli preferowanymi destynacjami BIZ są duże i dojrzałe rynki europejskie i pozaeuropejskie, to firmy najczęściej biorą pod uwagę czynniki efektywnościowe i społeczne. BIZ są lokowane na takich rynkach głównie w branży handlowej, przetwórstwa przemysłowego i w budownictwie. Ponadto wyborowi prawnych czynników podejmowania BIZ najczęściej towarzyszy wybór beneficjentów BIZ z korzystnymi rozwiązaniami podatkowymi, sprzyjającymi optymalizacji podatkowej. Inwestycje bezpośrednie są tam kierowane głównie w sektory związane z informacją i komunikacją oraz z działalnością profesjonalną i techniczną.

\section{Zakończenie}

Wyniki badań, jakość otrzymanych odwzorowań w analizie korespondencji, potwierdzily jej przydatność w profilowaniu firm, które planują bezpośrednie inwestycje zagraniczne. Z kolei zastosowanie hierarchicznej analizy skupień okazało się skuteczną metodą wspomagającą interpretację wyników analizy korespondencji. Profile potencjalnych eksporterów BIZ zostały wyodrębnione w oparciu o branże gospodarcze firm i preferowane motywy wyboru beneficjentów BIZ. Warto podkreślić, że segmentacja inwestorów może stanowić przesłanki do formułowania polityki inwestycyjnej tych firm lub może dostarczać wskazówek instytucjom i agendom rządowym wspierającym działania polskich inwestorów.

Badanie aktualnych motywów BIZ i łączenie ich z określonymi destynacjami wydaje się szczególnie ważne w obliczu dynamicznie zmieniającej się sytuacji gospodarczej, politycznej i społecznej na świecie. Owe zmiany powodują wzrost poziomu ryzyka różnych czynników, na które narażona jest firma inwestująca poza granicami kraju. Zatem przemyślany wybór kraju beneficjenta BIZ jest istotny, bo pozwala przynajmniej częściowo ograniczyć ryzyko towarzyszące międzynarodowej działalności gospodarczej firmy. Należy też zauważyć, że nowoczesne technologie, rozwój infrastruktury komunikacyjnej czy obniżenie kosztów transportu (np. lotniczego) w wielu częściach świata powoduje, że destynacje odległe geograficznie od Polski mogą być również atrakcyjne dla firm działających w określonych branżach. W różnych teoriach ekonomii można znaleźć wiele zestawień czynników decydujących o wyborze BIZ, jednak zmieniające się otoczenie gospodarcze, polityczne itp. powoduje konieczność ciągłej ich kwerendy, gdyż nie wszystkie one wytrzymują ,próbę tych zmian” i niektóre z nich bardziej zyskują na znaczeniu, a inne tracą swoje znaczenie. Skłania to do powtarzania w przyszłości tego typu badań, co ułatwi śledzenie aktualnych trendów w obszarze czynników wyboru BIZ przez polskich inwestorów. 


\section{Literatura}

Blasius J., 2001, Korrespondenzanalyse, Oldenbourg Verlag, München.

Clausen S.E., 1998, Applied Correspondence Analysis: An Introduction, Sage, University Paper 121.

Dunning J.H., 2004, Determinants of Foreign Direct Investment: Globalization-Induced Changes and the Role of Policies, [w:] Tungodden B., Stern N., Kolstad I. (ed.), Toward Pro-Poor Policies. Aid, Institutions and Globalization, World Bank, Washington.

Fry M.,1993, Foreign Direct Investment in a Macroeconomic Framework: Finance Efficiency, Incentives and Distortions, Working Paper WPS, no. 1141.

Greenacre M., 1993, Correspondence Analysis in Practice, Academic Press, London.

Jun K.W., Singh H., 1996, The determinants of foreign direct investment in developing countries, Transnational Corporations, vol. 5, no. 2, s. 67-105.

Karpińska-Mizielińska W., Smuga T., 2007, Determinanty bezpośrednich inwestycji polskich przedsiębiorstw na rynkach zagranicznych, Gospodarka Narodowa, $\mathrm{nr} 9$.

Kowalewski O., Radło M.J., 2013, Motywy inwestycji zagranicznych polskich przedsiębiorstw, Acta Universitatis Nicolai Copernici, Ekonomia, vol. 44, $\mathrm{nr} 2$.

Mottaleb K., 2007, Determinants of Foreign Direct Investment and Its Impact on Economic Growth in Developing Countries, MPRA Paper no. 9457.

Ozawa T., Lukas R.,1993, On the determinants of direct foreign investment: Evidence from East and Southeast Asia, World Development, no. 21.

Pilarska Cz., 2005, Bezpośrednie inwestycje zagraniczne w teorii ekonomii, Wydawnictwo Akademii Ekonomicznej w Krakowie, Kraków.

Rymarczyk J., 2004, Internacjonalizacja i globalizacja przedsiębiorstwa, PWE, Warszawa.

Salamaga M., 2015, Wielowymiarowa analiza statystyczna motywów podejmowania bezpośrednich inwestycji zagranicznych przez polskie firmy, Przegląd Statystyczny, t. 62, 4.

Sokal R.R., Rohlf F.J., 1962, The comparison of dendrograms by objective methods, Taxon, vol. 11, no. 2, s. 33-40.

Stanimir A., 2005, Analiza korespondencji jako narzędzie do badania zjawisk ekonomicznych, Wydawnictwo Akademii Ekonomicznej we Wrocławiu, Wrocław. 